\title{
Synthesis of $\left[{ }^{11} \mathrm{C}\right]-$ and $\left({ }^{13} \mathrm{C}\right)$-Cyanogen Bromide, Useful Electrophilic Labelling Precursors
}

\author{
Göran Westerberg and Bengt Långström \\ Uppsala University PET Centre, UAS S-751 85 Uppsala, Sweden
}

\begin{abstract}
Westerberg, G., Långström, B., 1993. Synthesis of $\left[{ }^{11} \mathrm{C}\right]-$ and $\left({ }^{13} \mathrm{C}\right)$-Cyanogen Bromide, Useful Electrophilic Labelling Precursors. - Acta Chem. Scand. 47: 974-978

A fast and simple route to the synthesis of $\left[{ }^{11} \mathrm{C}\right]$ - and $\left({ }^{13} \mathrm{C}\right)$-cyanogen bromide has been developed. Hydrogen $\left[{ }^{11} \mathrm{C}\right]$ cyanide was produced on-line from $\left[{ }^{11} \mathrm{C}\right]$ carbon dioxide and reacted with bromide in triethyleneglycol dimethyl ether to give a $70-80 \%$ decay-corrected radiochemical yield of $\left[{ }^{11} \mathrm{C}\right]$ cyanogen bromide in 9-11 min, counted from the end of the bombardment. In a typical run, starting from $20.5 \mathrm{GBq}(550 \mathrm{mCi})\left[^{11} \mathrm{C}\right]$ carbon dioxide, $10.1 \mathrm{GBq}(274 \mathrm{mCi})\left[{ }^{11} \mathrm{C}\right]$ cyanogen bromide were obtained. The $\left.{ }^{11} \mathrm{C}\right]$ cyanogen bromide was transferred to a reaction vessel in a stream of nitrogen gas and used in the synthesis of phenyl $\left[{ }^{11} \mathrm{C}\right]$ cyanate (1a), 4-nitrophenyl [ $\left.{ }^{11} \mathrm{C}\right]$ cyanate (1b), 2.4-dinitrophenyl $\left[{ }^{11} \mathrm{C}\right]$ cyanate (1c), diethyl [ $\left.{ }^{11} \mathrm{C}\right]$ cyanamide (2a), phenyl[ $\left.{ }^{11} \mathrm{C}\right]$ cyanamide (2b), diphenyl $\left[{ }^{11} \mathrm{C}\right]$ cyanamide (2c), 1-( $\left[{ }^{11} \mathrm{C}\right]$ cyano $)-4-($ dimethylamino)pyridinium bromide $(2 \mathrm{~d})$, and benzyl [ $\left.{ }^{11} \mathrm{C}\right]$ thiocyanate (3a). Compounds 1-3 were obtained with radiochemical yields of $54-98 \%$ in $13-27$ min counted from $\left[{ }^{11} \mathrm{C}\right.$ ]cyanogen bromide. Phenyl $\left[{ }^{11} \mathrm{C}\right]$ thiocyanate $(3 \mathrm{~b})$, was obtained in a $12 \%$ radiochemical yield. Using the procedure for benzyl $\left[{ }^{11} \mathrm{C}\right]$ thiocyanate $(3 \mathrm{a})$, benzyl $\left({ }^{13} \mathrm{C}\right)$ thiocyanate was obtained in $71 \%$ yield.
\end{abstract}

The interest in the incorporation of short-lived, positronemitting radionuclides into compounds of biological interest for use in positron emission tomography (PET) has prompted a search for new labelled synthetic precursors. Such labelled precursors might simplify the selection of synthetic strategies and increase the number of accessible target molecules.

In this paper, a method suitable for the routine production of $\left[{ }^{11} \mathrm{C}\right]$ cyanogen bromide is described, as well as the application of the labelled precursor for the synthesis of some simple model compounds. In a synthetic context, cyanogen bromide is an electrophilic one-carbon synthon which can be regarded as an umpoled cyanide species.

Hydrogen $\left[{ }^{11} \mathrm{C}\right]$ cyanide has long been used as a precursor for the synthesis of nitriles, carboxylic acids, amino acids, amines, and other labelling precursors. ${ }^{1}$ Cyanogen bromide as a source of positive cyanide, however, offers a range of new synthetic possibilities. Addition of an ${ }^{11} \mathrm{C}$-cyano-group to nucleophilic carbon, nitrogen, oxygen or sulfur presents new routes to labelled products and synthetic intermediates, e.g., nitriles, cyamides, cyanates and thiocyanates. Cyanogen bromide $(\mathrm{CNBr})$ has previously been used primarily as a reagent in protein chemistry for the selective cleavage of peptide bonds, ${ }^{2}$ and as a chromatography resin activating agent ${ }^{3}$ and in the von Braun degradation of amines. ${ }^{4}$ The synthesis of carrier-added $\left[{ }^{14} \mathrm{C}\right]$ cyanogen bromide has been reported. ${ }^{5}$ $\left[{ }^{11} \mathrm{C}\right]$ Cyanogen bromide was prepared by the reaction between hydrogen $\left[{ }^{11} \mathrm{C}\right.$ ]cyanide and bromine in triethyleneglycol dimethyl ether (triglyme) at room temperature and then distilled into the reaction flask, as shown in Fig. 1. The $\left[{ }^{11} \mathrm{C}\right]$ cyanogen bromide was used in the synthesis of the labelled aromatic cyanates phenyl $\left[{ }^{11} \mathrm{C}\right]$ cyanate (1a), 4-nitrophenyl $\left[{ }^{11} \mathrm{C}\right]$ cyanate (1b) and 2,4-dinitrophenyl $\left[{ }^{11} \mathrm{C}\right]$ cyanate $(1 \mathrm{c})$ according to Scheme 1. Labelled cyanamides were obtained by the reaction of $\left[{ }^{11} \mathrm{C}\right]$ cyanogen bromide with various amines

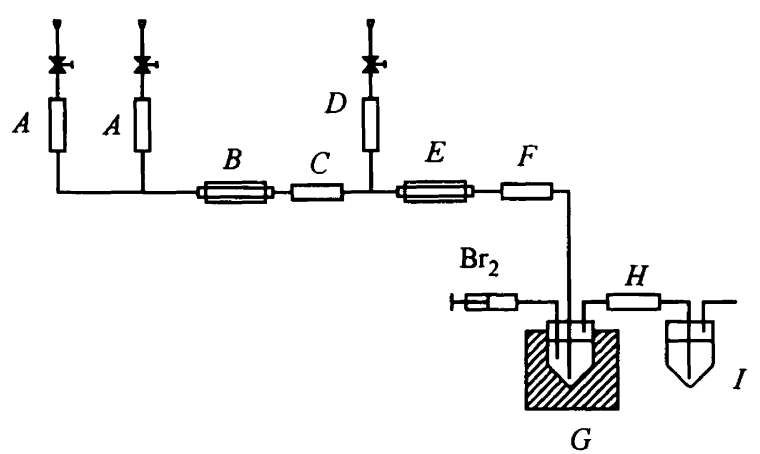

Fig. 1. System used for the on-line production of hydrogen $\left[{ }^{11} \mathrm{C}\right]$ cyanide and synthesis of $\left[{ }^{11} \mathrm{C}\right]$ cyanogen bromide. A, $\mathrm{MgClO}_{4}$; B, Ni-furnace (Ni/Kiselguhr), $400^{\circ} \mathrm{C} ; \mathrm{C}$, Ascarite- $\mathrm{MgClO}_{4} ; \mathrm{D}, \mathrm{KOH} ; \mathrm{E}, \mathrm{Pt}$-furnace, $1050^{\circ} \mathrm{C} ; \mathrm{F}, \mathrm{P}_{2} \mathrm{O}_{5}$; $\mathrm{G}$, heating block with glass reaction vessel; $\mathrm{H}, \mathrm{Sb}$-powder; $\mathrm{I}$, receiving vessel. 


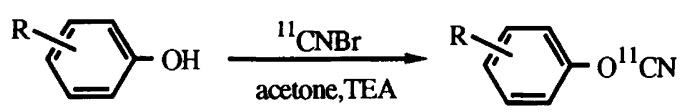

(1) a $\mathrm{R}=\mathrm{H}$

b $\mathrm{R}=4-\mathrm{NO}_{2}$

c $\mathrm{R}=2,4-\mathrm{NO}_{2}$

Scheme 1.

and gave the following products: diethyl $\left[{ }^{11} \mathrm{C}\right]$ cyanamide (2a), phenyl $\left[{ }^{11} \mathrm{C}\right]$ cyanamide (2b), diphenyl $\left[{ }^{11} \mathrm{C}\right]-$ cyanamide (2c) and 1-([ $\left.{ }^{11} \mathrm{C}\right]$ cyano)-4-(dimethylamino)pyridinium bromide (2d), as illustrated in Scheme 2.

$$
\begin{aligned}
& \mathrm{R}^{1} \mathrm{R}^{2} \mathrm{NH} \underset{\mathrm{THF} \text { or DMSO }}{\stackrel{{ }^{1}{ }^{1} \mathrm{CNBr}}{\longrightarrow}} \quad \mathrm{R}^{1} \mathrm{R}^{2} \mathrm{~N}^{11} \mathrm{CN} \\
& \text { (2) a } \mathrm{R}^{1}=\mathrm{R}^{2}=\text { ethyl } \\
& \text { b } R^{1}=H, R^{2}=\text { phenyl } \\
& \text { c } \mathrm{R}^{1}=\mathrm{R}^{2}=\text { phenyl }
\end{aligned}
$$

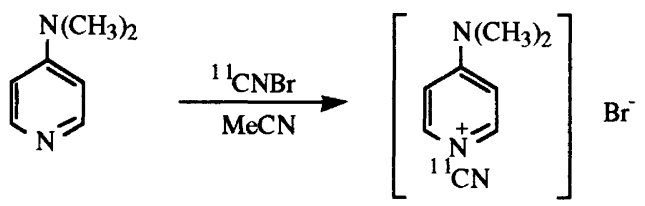

(2d)

Scheme 2

Benzyl sulfide ion and thiophenol were used to synthesise benzyl $\left[{ }^{11} \mathrm{C}\right]$ thiocyanate (3a) and phenyl $\left[{ }^{11} \mathrm{C}\right]$ thiocyanate (3b), respectively, according to Scheme 3 .
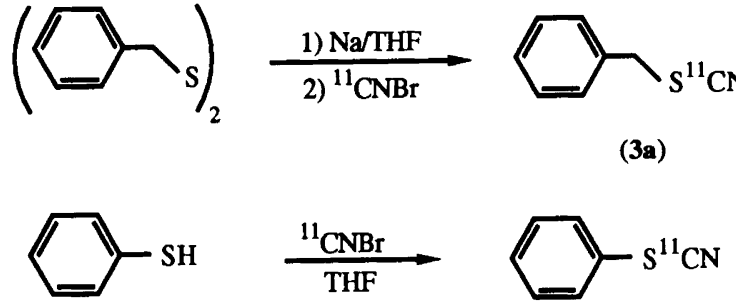

(3b)

Scheme 3.

The synthesis of biologically active compounds labelled with stable nuclides is receiving increased attention as a result of the development in the fields of mass spectroscopy and nuclear magnetic resonance spectroscopy. Using a procedure analogous to $\left[{ }^{11} \mathrm{C}\right]$ cyanogen bromide, $\left({ }^{13} \mathrm{C}\right)$ cyanogen bromide was prepared and used in the synthesis of benzyl $\left({ }^{13} \mathrm{C}\right)$ thiocyanate in a high chemical yield.

\section{Materials and methods}

General. $\left[{ }^{11} \mathrm{C}\right]$ Carbon dioxide was prepared by the ${ }^{14} \mathrm{~N}(\mathrm{p}, \alpha){ }^{11} \mathrm{C}$ nuclear reaction using a nitrogen gas target and the tandem Van der Graaf accelerator at the The Svedberg Laboratory, University of Uppsala, and recently the Scanditronix MC-17 cyclotron at the Uppsala University PET Centre. The $\left[{ }^{11} \mathrm{C}\right]$ carbon dioxide was converted into hydrogen $\left[{ }^{11} \mathrm{C}\right]$ cyanide using the Scanditronix RNP-17 gas processing system according to a general procedure described previously. ${ }^{6,7}$

Analytical HPLC was performed on a Hewlett Packard model 1090 equipped with a UV-diode array detector in series with a $\beta^{+}$-flow detector ${ }^{8}$ and the following columns: (A) $\mathrm{C}_{18}$ Spherisorb ODS $110 \mu \mathrm{m}, 250 \times 4.6 \mathrm{~mm}$ (i.d.); (B) $\mathrm{C}_{18}$ Nucleosil $10 \mu \mathrm{m}, 250 \times 4.6 \mathrm{~mm}$ (i.d.). Mobile phases used were: (C) $0.05 \mathrm{M}$ ammonium formate $\mathrm{pH} 3.5$; (D) $0.01 \mathrm{M}$ potassium dihydrogenphosphate, $\mathrm{pH} 4.6$; (E) methanol and (F) acetonitrile-water $(50: 7, \mathrm{v} / \mathrm{v})$. Preparative HPLC was performed with a Waters M-45 pump and a $\mathrm{C}_{18}$ Nucleosil $10 \mu \mathrm{m} 250 \times 10 \mathrm{~mm}$ (i.d.) column with a Pharmacia Dual Path Monitor UV-2 in series with a Philips ZP-114 GM-tube. Gas chromatography was performed on a Hewlett Packard 5880A equipped with a flame ionization detector in series with a $\beta^{+}$-flow detector ${ }^{9}$ and a $1 \mathrm{~m} 1 / 8^{\prime \prime}$ glass column packed with $20 \%$ SE-52 on $110 / 120$ Chromosorb W, with a flow rate of $30 \mathrm{ml} \mathrm{min}{ }^{-1}\left(\mathrm{~N}_{2}\right)$. ${ }^{13} \mathrm{C}$ NMR spectra were recorded on a Varian XL-300 at $75.4 \mathrm{MHz}\left(\mathrm{CDCl}_{3}\right)$. Tetrahydrofuran (THF) and triethyleneglycol dimethyl ether (triglyme) were dried by distillation from sodiumbenzophenone and sodium hydride, respectively.

Synthesis of $\left[{ }^{11} \mathrm{C}\right]$ cyanogen bromide. Hydrogen $\left[{ }^{11} \mathrm{C}\right]-$ cyanide was trapped in $800 \mu$ l triethyleneglycol dimethyl ether (triglyme) at room temperature. Bromine (Merck, zur synthese) was dissolved in $300 \mu$ l triglyme immediately prior to use and then added to the reaction vessel through a septum. The reaction mixture was heated to $180^{\circ} \mathrm{C}$ in a heating block and the $\left[{ }^{11} \mathrm{C}\right]$ cyanogen bromide transferred in a stream of nitrogen via a tube containing ca. $400 \mathrm{mg}$ antimony powder dispersed on glass beads, to a receiving vessel for further synthesis. The $\left[{ }^{11} \mathrm{C}\right]$ cyanogen bromide was analysed by HPLC using column A, solvent $\mathrm{C} / \mathrm{E}$, isocratic elution at $80: 20 \mathrm{v} / \mathrm{v}$, flow $2 \mathrm{ml} \mathrm{min}^{-1}$, column temperature $40^{\circ} \mathrm{C}$. The retention times for $\left[{ }^{11} \mathrm{C}\right]$ cyanogen bromide and $\left[{ }^{11} \mathrm{C}\right]$ cyanide ion were 2.4 and $1.8 \mathrm{~min}$, respectively. GC analysis with a column temperature of $60^{\circ} \mathrm{C}$ gave a retention time for $\left[{ }^{11} \mathrm{C}\right]$ cyanogen bromide of $1.9 \mathrm{~min}$.

Synthesis of phenyl $\left[{ }^{11} \mathrm{C}\right]$ cyanate, 4-nitrophenyl [ $\left.{ }^{11} \mathrm{C}\right]-$ cyanate and 2,4-dinitrophenyl $\left.{ }^{11} C\right]$ cyanate, compounds (1a-c). The phenol $(50 \mu \mathrm{mol})$ was dissolved in $600 \mu \mathrm{l}$ of dry acetone in a $1.5 \mathrm{ml}$ vial equipped with a septum. Triethylamine ( $5 \mu \mathrm{l}, 1.4$ equiv.) was added and the $\left[{ }^{11} \mathrm{C}\right]$ cyanogen bromide was transferred in a stream of nitrogen to the cooled $\left(-72^{\circ} \mathrm{C}\right)$ reaction mixture. After transfer of the radioactivity, the solution was heated at $70^{\circ} \mathrm{C}$ for $2 \mathrm{~min}$ and then evaporated to dryness. The residue was taken up in $2 \mathrm{ml}$ acetonitrile and, in the case of phenyl [ $\left.{ }^{11} \mathrm{C}\right]$ cyanate (1a), injected into the preparative 
HPLC using a column temperature of $25^{\circ} \mathrm{C}$, solvent $\mathrm{C} / \mathrm{E}$, isocratic elution at $70: 30 \mathrm{v} / \mathrm{v}$, flow $5 \mathrm{ml} \mathrm{min}^{-1}$, wavelength $254 \mathrm{~nm}$. The fraction with a retention time of 7.7 min was collected and analysed (column B, solvents $\mathrm{C} / \mathrm{E}$, isocratic elution at $70: 30 \mathrm{v} / \mathrm{v}$, flow $2 \mathrm{ml} \mathrm{min}^{-1}$, column temperature $40^{\circ} \mathrm{C}$, wavelength $254 \mathrm{~nm}$ ). The retention times of the compounds $1 \mathrm{a}, 1 \mathbf{b}$ and $1 \mathrm{c}$ were $6.3,5.8$ and $5.5 \mathrm{~min}$, respectively.

Synthesis of diethyl $\left[^{11} C\right]$ cyanamide (2a). Diethylamine $(10 \mu \mathrm{l}, 100 \mu \mathrm{mol})$ was dissolved in $600 \mu \mathrm{l}$ THF in a $1.5 \mathrm{ml}$ vial equipped with a septum. The $\left[{ }^{11} \mathrm{C}\right]$ cyanogen bromide was transferred to the cooled $\left(-72^{\circ} \mathrm{C}\right)$ reaction vessel in a stream of nitrogen. After transfer of the radioactivity, the solution was heated at $70^{\circ} \mathrm{C}$ for $1 \mathrm{~min}$, and then purified by preparative HPLC, using the following conditions: column temperature $25^{\circ} \mathrm{C}$, solvent

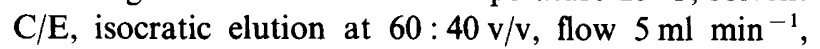
wavelength $254 \mathrm{~nm}$. The fraction with a retention time of $3.8 \mathrm{~min}$ was collected. The radiochemical purity was $>98 \%$ as analysed by HPLC (column B and solvents $\mathrm{D} / \mathrm{F}$, isocratic elution at $80: 20 \mathrm{v} / \mathrm{v}$, flow $2 \mathrm{ml} \mathrm{min}^{-1}$, column temperature $40^{\circ} \mathrm{C}$, wavelength $230 \mathrm{~nm}$ ). The retention time for $2 \mathrm{a}$ was $6.7 \mathrm{~min}$.

Synthesis of phenyl ["C]cyanamide (2b). Aniline $(100 \mu \mathrm{mol})$ was dissolved in $600 \mu \mathrm{l}$ DMSO in a $1.5 \mathrm{ml}$ vial equipped with a septum. The $\left[{ }^{11} \mathrm{C}\right]$ cyanogen bromide was transferred to this vial at room temperature. The reaction mixture was heated at $120^{\circ} \mathrm{C}$ for $4 \mathrm{~min}$, when a sample was taken for HPLC analysis (column B and solvents $\mathrm{D} / \mathrm{F}$, isocratic elution at $80: 20 \mathrm{v} / \mathrm{v}$, flow $2 \mathrm{ml}$ $\min ^{-1}$, column temperature $40^{\circ} \mathrm{C}$, wavelength $254 \mathrm{~nm}$ ). The retention time of aniline $\left[{ }^{11} \mathrm{C}\right]$ cyanamide was $6.8 \mathrm{~min}$.

Synthesis of diphenyl ${ }^{11}$ CJcyanamide (2c). To a solution of diphenylamine $(8.5 \mathrm{mg}, 50 \mu \mathrm{mol})$ in THF $(100 \mu \mathrm{l})$ held at $-72^{\circ} \mathrm{C}$ were added $40 \mu \mathrm{l} n$-butyllithium $(1.6 \mathrm{M}$ in hexane, 1.3 equiv.). $\left[{ }^{11} \mathrm{C}\right] \mathrm{Cyanogen}$ bromide was trapped in $400 \mu \mathrm{l}$ THF at $-72^{\circ} \mathrm{C}$ in a $1.5 \mathrm{ml}$ septum-sealed reaction vessel. After trapping, the radioactivity was transferred to the amine solution, and allowed to react at $-72^{\circ} \mathrm{C}$ for $2 \mathrm{~min}$, when $25 \mu \mathrm{l}$ water were added. The reaction mixture was analysed using the same conditions as for phenyl $\left[{ }^{11} \mathrm{C}\right]$ cyanamide. The retention time of the product $2 \mathrm{c}$ was $9.1 \mathrm{~min}$.

Synthesis of 1-([ $\left.{ }^{11} C\right]$ cyano $)-4-($ dimethylamino $)$ pyridinium bromide (2d). [ $\left.{ }^{11} \mathrm{C}\right]$ Cyanogen bromide was trapped in a solution containing $6.0 \mathrm{mg}(50 \mu \mathrm{mol})$ 4-(dimethylamino)pyridine in $600 \mu$ acetonitrile. This solution was heated at $70^{\circ} \mathrm{C}$ for $2 \mathrm{~min}$ and then diluted with $1.0 \mathrm{ml}$ mobile phase and injected into the preparative HPLC column, temperature $25^{\circ} \mathrm{C}$, solvent $\mathrm{C} / \mathrm{E}$, isocratic elution

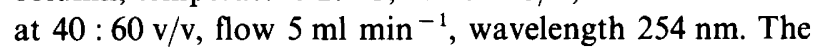
fraction with a retention time of $4.1 \mathrm{~min}$ was collected. HPLC analysis using column (B), solvents C/E, isocratic elution $80: 20 \mathrm{v} / \mathrm{v}$, column temperature $40^{\circ} \mathrm{C}$ and a wavelength $254 \mathrm{~nm}$ gave a retention time of 5.6 minutes for (2d).

Synthesis of benzyl [ ${ }^{11}$ C]thiocyanate (3a). Dibenzyl disulphide $(12.3 \mathrm{mg}, 50 \mu \mathrm{mol})$ was dissolved in THF $(600 \mu \mathrm{l})$ and treated with sodium $(3.3 \mathrm{mg}, 140 \mu \mathrm{mol})$ at $-72^{\circ} \mathrm{C}$. The $\left[{ }^{11} \mathrm{C}\right]$ cyanogen bromide was transferred to this solution in a stream of nitrogen after which the reaction mixture was heated at $80^{\circ} \mathrm{C}$ for $5 \mathrm{~min}$. The resulting solution was diluted to $1.0 \mathrm{ml}$ with HPLC mobile phase and injected into the preparative HPLC, solvent $\mathrm{C} / \mathrm{E}$, flow $5 \mathrm{ml} \mathrm{min}{ }^{-1}$, retention time $7.0 \mathrm{~min}$. The fraction containing 3a was collected and analysed (column B, mobile phase C/E, $80: 20 \mathrm{v} / \mathrm{v}$, linear gradient $20-80 \% \mathrm{E}$, $0-5 \mathrm{~min}$, flow $2 \mathrm{ml} \mathrm{min}^{-1}$, wavelength $254 \mathrm{~nm}$ ). The retention time of benzyl [ ${ }^{11} \mathrm{C}$ ] thiocyanate was $8.3 \mathrm{~min}$.

Synthesis of benzyl $\left({ }^{13} \mathrm{C}\right)$ thiocyanate. Potassium $\left({ }^{13} \mathrm{C}\right)$ cyanide $(8.1 \mathrm{mg}, 123 \mu \mathrm{mol})$ was dissolved in $20 \mu \mathrm{l}$ water and added to the triglyme. Hydrogen $\left[{ }^{11} \mathrm{C}\right]$ cyanide was trapped in this solution, bromine $(125 \mathrm{mg}, 780 \mu \mathrm{mol})$ in $300 \mu \mathrm{l}$ triglyme was added and the reaction mixture allowed to stand for $2 \mathrm{~min}$. A drying tower containing phosphorus pentaoxide (Sicapent ${ }^{\circledR}$ ) was incorporated in series with the antimony bed and the reaction mixture treated as described above. The mixture of $\left[{ }^{11} \mathrm{C}\right]-$ cyanogen bromide and $\left({ }^{13} \mathrm{C}\right)$ cyanogen bromide was transferred to a $3 \mathrm{ml}$ vessel containing $29.3 \mathrm{mg}(120 \mu \mathrm{mol})$ dibenzyl disulphide and $10.3 \mathrm{mg}(450 \mu \mathrm{mol})$ sodium. After transfer, the reaction mixture was heated at $80^{\circ} \mathrm{C}$ for $10 \mathrm{~min}$. The reaction was quenched by the addition of $250 \mu \mathrm{l}$ of $2 \mathrm{M} \mathrm{HCl}$, and then injected into the preparative

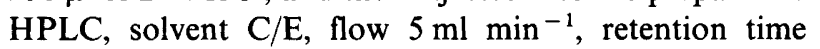
$6.6 \mathrm{~min}$. The fraction containing labelled benzyl thiocyanate was collected and analysed (column $\mathrm{B}$, mobile phase C/E, $80: 20 \mathrm{v} / \mathrm{v}$, linear gradient $20-80 \% \mathrm{E}$,

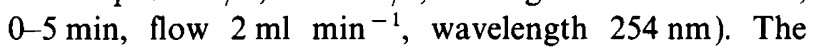
product fraction was evaporated and the residue dissolved in $\mathrm{CDCl}_{3} \cdot{ }^{13} \mathrm{C} \mathrm{NMR}$ spectroscopy gave a chemical shift of $112.0 \mathrm{ppm}$ for the single peak detected, using the $\mathrm{CDCl}_{3}$ signal (77 ppm) as the reference. The ${ }^{13} \mathrm{C}$ NMR spectrum of a reference sample ${ }^{12}$ of benzyl thiocyanate showed peaks at 38.2, 112.0, 128.8, 128.9, 129.0 and $134.3 \mathrm{ppm}$.

Synthesis of phenyl $\left[{ }^{11}\right.$ C]thiocyanate (3b). The synthesis of phenyl $\left[{ }^{11} \mathrm{C}\right]$ thiocyanate was carried out in THF by a procedure analogous to that of phenyl $\left[{ }^{11} \mathrm{C}\right]$ cyanate. After heating, the reaction mixture was analysed using the same conditions as for benzyl $\left[{ }^{11} \mathrm{C}\right]$ thiocyanate. The retention time of $(\mathbf{3 b})$ was $5.9 \mathrm{~min}$.

\section{Results and discussion}

Production of hydrogen $\left[{ }^{11} \mathrm{C}\right]$ cyanide from $\left[{ }^{11} \mathrm{C}\right]$ carbon dioxide was performed using an on-line procedure as described previously. ${ }^{6,7} \mathrm{~A}$ drying tower containing 


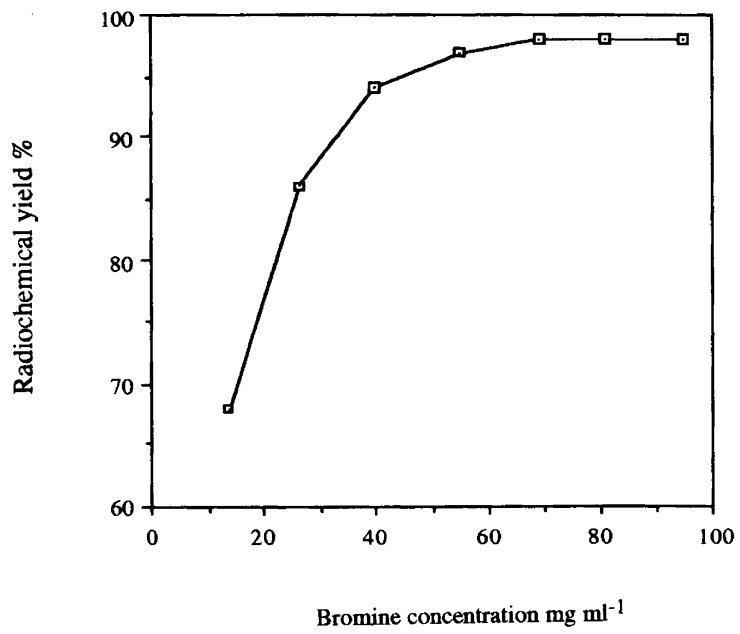

Fig. 2. Radiochemical yield for the conversion of hydrogen $\left[{ }^{11} \mathrm{C}\right]$ cyanide into $\left[{ }^{11} \mathrm{C}\right]$ cyanogen bromide vs. amount of bromine used. Yields were measured after trapping of $\left[{ }^{11} \mathrm{C}\right]$ cyanogen bromide.

phosphorus pentaoxide (Sicapent ${ }^{\circledR}$ ) was incorporated after the platinum furnace to trap and reduce the amount of ammonia in the reaction vessel, Fig. 1.

The synthesis of $\left[{ }^{11} \mathrm{C}\right]$ cyanogen bromide was carried out in a glass reaction vessel equipped with a septum. The total volume of this vessel was $6.0 \mathrm{ml}$.

When transferring the $\left[{ }^{11} \mathrm{C}\right]$ cyanogen bromide from the reaction vessel, it was found that the excess of bromine could be efficiently removed from the gas-stream using a tube filled with antimony powder dispersed on glass beads, provided that fresh antimony was used in each run. ${ }^{10}$ The efficiency of the removal of bromine was checked using a modified literature procedure. ${ }^{11}$ It was found that more than $98 \%$ of the bromine used was retained on the antimony bed.

Synthesis of $\left[{ }^{11} C\right]$ cyanogen bromide. In search of suitable conditions for the preparation of $\left[{ }^{11} \mathrm{C}\right]$ cyanogen

Table 1. Radiochemical yields and synthesis times.

\begin{tabular}{|c|c|c|}
\hline Product & $\begin{array}{l}\text { Radiochemical } \\
\text { yield }(\%)^{a}\end{array}$ & $\begin{array}{l}\text { Synthesis } \\
\text { time }^{b} / \mathrm{min}\end{array}$ \\
\hline$\left[{ }^{11} \mathrm{C}\right]$ Cyanogen bromide & $98 \pm 1,3^{c}$ & 7 \\
\hline Phenyl [" $\mathrm{C}]$ cyanate $(\mathbf{1} \mathrm{a})$ & $81(73)$ & $16(26)$ \\
\hline 4-Nitrophenyl $\left[{ }^{11} \mathrm{C}\right]$ cyanate $(\mathbf{1 b})$ & $84(-)$ & $15(-)$ \\
\hline 2,4-Dinitrophenyl [ $\left.{ }^{11} \mathrm{C}\right]$ cyanate $(1 \mathrm{c})$ & $78(-)$ & $16(-)$ \\
\hline Diethyl $\left[{ }^{11} \mathrm{C}\right]$ cyanamide $(\mathbf{2 a})$ & $97(93)$ & $13(22)$ \\
\hline Phenyl $\left[{ }^{11} \mathrm{C}\right]$ cyanamide $(2 \mathrm{~b})$ & $86(-)$ & $17(-)$ \\
\hline DiphenyI $\left[{ }^{11} \mathrm{C}\right]$ cyanamide $(2 \mathrm{c})$ & $54(-)$ & $18(-)$ \\
\hline 1-([11 C]cyano) -4-(dimethyl- & & \\
\hline amino) pyridinium bromide (2d) & $98(96)$ & $14(23)$ \\
\hline Benzyl $\left[{ }^{11} \mathrm{C}\right]$ thiocyanate $(3 a)$ & $93(87)$ & $17(27)$ \\
\hline Phenyl $\left[{ }^{11} \mathrm{C}\right]$ thiocyanate $(3 \mathrm{~b})$ & $12(-)$ & $16(-)$ \\
\hline
\end{tabular}

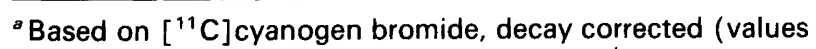
within parentheses after preparative HPLC). ${ }^{b}$ Counted from $\left[{ }^{11} \mathrm{C}\right]$ cyanogen bromide. ${ }^{c}$ Based on hydrogen $\left[{ }^{11} \mathrm{C}\right]$ cyanide, mean yield \pm S.D. $(n=64)$. bromide, the reaction was performed in a range of polar and non-polar solvents: glacial acetic acid, ethanol, DMSO, DMF, THF, triglyme and diethyl ether. The highest yields were obtained in triglyme and THF, while use of the polar solvents resulted in complex product mixtures or low yields. Triglyme was found to be an ideal solvent owing to its inertness and high boiling point $\left(225^{\circ} \mathrm{C}\right)$, allowing the transfer of the $\left[{ }^{11} \mathrm{C}\right]$ cyanogen bromide while minimizing codistillation of solvent. The trapping efficiency of hydrogen $\left[{ }^{11} \mathrm{C}\right]$ cyanide in triglyme was monitored by placing an Ascarite ${ }^{\circledR}$ trap in series with the reactor, and was found to be higher than $98 \%$ at the carrier gas flow used $\left(60-80 \mathrm{ml} \mathrm{min}^{-1}\right)$.

Freshly prepared solutions of bromine in triglyme were required to achieve high yields of $\left[{ }^{11} \mathrm{C}\right]$ cyanogen bromide. Once prepared, the bromine solutions were used within $1 \mathrm{~h}$, otherwise resinous products were formed in the reaction vessel causing significantly lower yields.

The yield of the conversion into $\left[{ }^{11} \mathrm{C}\right]$ cyanogen bromide was determined prior to distillation using HPLC. The yield as a function of the amount of bromine used was determined by varying the amount over a range of $5-35 \mu \mathrm{l}(15-110 \mathrm{mg}, 10-70 \mu \mathrm{mol})$. The results are presented in Fig. 2. In a typical run, $20 \mu \mathrm{l}(60 \mathrm{mg})$ of bromine were used.

As seen in Table 1, the yield of the conversion of hydrogen $\left[{ }^{11} \mathrm{C}\right]$ cyanide into $\left[{ }^{11} \mathrm{C}\right]$ cyanogen bromide was high and reproducible. Traces of unchanged hydrogen $\left[{ }^{11} \mathrm{C}\right]$ cyanide could be detected in the reaction mixture before distillation, but no other labelled products were observed as analyzed by HPLC. After transfer from the reaction vessel, the only detectable labelled product was $\left[{ }^{11} \mathrm{C}\right]$ cyanogen bromide. It is conceivable that the small amount of unchanged hydrogen $\left[{ }^{11} \mathrm{C}\right]$ cyanide was retained on the antimony tube used for the removal of bromine.

The specific radioactivity of benzyl $\left[{ }^{11} \mathrm{C}\right]$ thiocyanate was determined using HPLC to be $229 \mathrm{GBq} \mu \mathrm{mol}^{-1}$ $\left(6.2 \mathrm{Ci} \mu \mathrm{mol}^{-1}\right)$ at the end of synthesis (synthesis time $17 \mathrm{~min}$ ). This is in accordance with the value obtained for the hydrogen $\left[{ }^{11} \mathrm{C}\right]$ cyanide as analysed by other methods.

Synthesis of ${ }^{11}$ C-labelled cyanates, cyanamides and thiocyanates. The labelled cyanates phenyl $\left[{ }^{11} \mathrm{C}\right]$ cyanate, 4-nitrophenyl $\left[{ }^{11} \mathrm{C}\right]$ cyanate and 2,4-dinitrophenyl $\left[{ }^{11} \mathrm{C}\right]$ cyanate $(\mathbf{1 a}-\mathbf{c})$ were prepared analogously to literature procedures, ${ }^{13}$ according to Scheme 1 . No sign of trimerisation was detected, most likely because of the low concentration of labelled product in the reaction mixture.

Interestingly, no difference in reactivity between the phenols was seen. All three, including the strongly deactivated 2,4-dinitrophenol, gave high yields of the respective cyanate, without any contaminating by-products.

Aromatic cyanates have been mentioned as useful electrophiles in reaction with a range of nucleophiles. ${ }^{14}$ 
$\left[{ }^{11} \mathrm{C}\right]$ Cyanamide has been prepared by proton irradiation of calcium nitride and has been used in the synthesis of ${ }^{11} \mathrm{C}$-labelled benzylguanidine. ${ }^{15}$ The preparation of the labelled cyanamides using $\left[{ }^{11} \mathrm{C}\right]$ cyanogen bromide, however, constitutes a new and versatile route to these compounds, as shown in the synthesis of diethyl $\left[{ }^{11} \mathrm{C}\right]$ cyanamide, phenyl $\left[{ }^{11} \mathrm{C}\right]$ cyanamide, diphenyl$\left[{ }^{11} \mathrm{C}\right]$ cyanamide and 1-([ $\left.{ }^{11} \mathrm{C}\right]$ cyano $)-4$-(dimethylamino)pyridinium bromide (2a-d), Scheme 2. Nearquantitative yields were obtained in very short synthesis times, regardless of the wide range in reactivity of the amines. The aliphatic amine gave a high yield of product at room temperature in only 1-2 min reaction time, while the aromatic amines required more vigorous conditions. In the case of $N, N$-diphenylamine, deprotonation using butyllithium was required to form the cyanamide $\mathbf{2 c}$.

$\mathrm{N}$-Cyanoammonium compounds are used as highly reactive cyanation agents ${ }^{16,17}$ but have, to our knowledge, not previously been labelled with radionuclides. The synthesis of 1-([ $\left.{ }^{11} \mathrm{C}\right]$ cyano $)-4-($ dimethylamino $)$ pyridinium bromide proceeded in a very high yield to give a product which, after evaporation of the solvent, is available for further synthesis, without the need for prior purification.

The synthesis of benzyl $\left[{ }^{11} \mathrm{C}\right]$ thiocyanate proceeded in $93 \%$ yield without the formation of labelled by-products. However, thiophenol gave only a very low yield $(12 \%)$ of phenyl $\left[{ }^{11} \mathrm{C}\right]$ thiocyanate. This can be explained by displacement of $\left[{ }^{11} \mathrm{C}\right]$ cyanide by attack of thiophenol on the thiocyanate formed, yielding phenyl disulfide. ${ }^{17}$

Position of the label and compound identity. To confirm the labelling position, $\left({ }^{13} \mathrm{C}\right)$ cyanogen bromide was synthesized in combination with $\left[{ }^{11} \mathrm{C}\right]$ cyanogen bromide and used in the simultaneous synthesis of benzyl $\left({ }^{13} \mathrm{C}\right)$ thiocyanate and benzyl $\left[{ }^{11} \mathrm{C}\right]$ thiocyanate. The ${ }^{13} \mathrm{C}$ NMR spectrum of this compound was then compared with a sample prepared by a literature procedure. ${ }^{12}$ One large peak was obtained, corresponding to the cyanate carbon atom assigned from a spectrum of the reference compound.

The yield of this reaction was $71 \%$ as determined by HPLC, suggesting the general usefulness of this procedure for the synthesis of labelled compounds of this type.

HPLC-analysis was performed by adding unlabelled reference compound to the radioactive samples and comparing the UV spectra and radiochromatograms. The reference compounds were prepared according to literature procedures or with procedures corresponding to the labelling syntheses. All reference compounds were characterised using ${ }^{1} \mathrm{H}$ and ${ }^{13} \mathrm{C}$ NMR spectroscopy.

Work is now in progress to develop $\left[{ }^{11} \mathrm{C}\right]$ cyanogen bromide as a labelling precursor in the synthesis of labelled molecules of more relevant biological interest. Also, the possibility of converting $\left[{ }^{11} \mathrm{C}\right]$ cyanogen bromide into other reactive intermediates, such as guanidine and urea is being investigated.

Acknowledgments. We are indebted to Dr. P. Malmborg for assistance in radionuclide production at the The Svedberg Laboratory and to Professor Åke Olin for the bromine analyses. This work was financially supported by the Swedish Natural Science Research Council, grant No. K-KU 3463.

\section{References}

1. Hörnfeldt, K., Antoni, G. and Långstrom, B. Acta Chem. Scand. 46 (1992) 87.

2. Gross, E. and Witkop, B. J. Biol. Chem. 237 (1962) 1856.

3. Kohn. J. and Wilchek. M. Appl. Biochem. Biotech. 9 (1984) 285.

4. Hageman, H. A. Organic Reactions, Wiley, New York, 1953, Vol. VII, pp. 198-263.

5. White, D. F. and Burns, J. J. Labelled Compd. Radiopharm. $11(1975) 171$.

6. Christman, D. R., Finn, R. D., Karlstrom, K. and Wolf, A. P. Int. J. Appl. Radiat. Isot. 26 (1975) 435.

7. Iwata, R., Ido, T., Takahashi, T., Nakanishi, H. and Iida, S. Appl. Radiat. Isot. 38 (1987) 97.

8. Långström, B. and Lundqvist, H. Radiochem. Radioanal. Lett. 41 (1979) 375.

9. Långström, B., Gullberg, P. and Lundqvist, H. ICUU Technical Report, Chemical Institute, Uppsala University, Sweden 1985.

10. Roeda, D., Crouzel, C. and van Zanten, B. Radiochem. Radioanal. Lett. 33 (1978) 175.

11. Lundström, U. Talanta 29 (1982) 291.

12. Beilstein, Springer Verlag, Berlin 1923 Band VI : 2, 460i.

13. Grigat, E. and Pütter, R. Chem. Ber. 97 (1964) 3012; Grigat, E. and Pütter, R. ibid. 3018; Grigat, E. and Pütter, R. ibid. 3022; Grigat, E. and Pütter, R. ibid., 3027; Grigat, E., Pütter, R., Schneider, K. and Wedemeyer, K. F. ibid. 3036.

14. Hedayatullah, M. Bull. Soc. Chim. 4 (1968) 1572.

15. Iwata, R. and Ido, T. Int. J. Appl. Radiat. Isot. 34 (1983) 973.

16. Fodor, G., Abidi, S. and Carpenter, T. C. J. Org. Chem. 39 (1974) 1507.

17. Paukstelis, J. V. and Kim, M. J. Org. Chem. 39 (1974) 1494.

Received November 5, 1992. 